\title{
National Parties and Group Membership in the European Parliament: Ideology or Pragmatism?
}

\author{
by Edoardo Bressanelli ${ }^{1}$
}

\begin{abstract}
This paper investigates the factors behind political Group membership in the European Parliament. At the beginning of each legislative term, political Groups are formally constituted. In June 2009, more than 150 national parties, from the 27 member countries of the EU, joined one of the seven transnational groupings. Two main explanations of Group membership are advanced. A first, traditional argument for Group membership is based on the ideological or policy compatibility of the member parties within each political Group. National parties will join the political Group that best matches their programmatic position. A second argument focuses, instead, on the structure of incentives in the European Assembly, positing that the office and pragmatic goals of national parties are better advanced by joining the largest and most influential Groups. These arguments are tested by fitting a multinomial logit model for political Group 'choice' based on the 2009 Euromanifestos data. The findings suggest that ideology or policy compatibility is the most important factor behind a party transnational affiliation. A note of caution is, however, warranted for the new members of Central and Eastern Europe, whose ideological fit in the political Groups appears to be more problematic than for West European parties.
\end{abstract}

\section{Introduction}

A few decades ago or so, it was customary for parties in the European People's Party to label themselves 'Christian-Democrats', while no national party in the Group of the Party of the European Socialists would omit from its official party label the word 'Socialist', 'Progressive', 'Labour', or some other variant. By simply scrolling down the list of the member parties of any political Group in the European Parliament (EP) today, and by looking at their names, the difference is quite starking. Thus, we discover that the 'Social Democrats' in Portugal sit with the EPP, after having been for a short time members in the Liberal Group. We can also find out that the Romanian Democratic Liberal Party is, rather, a member of the EPP, or that the Italian Democrats - once led by the left-wing Christian-Democrat and former Commission President Romano Prodi - are allies with the Socialists. These few illustrations should make evident the reason why an experienced practitioner in the EU has described the EP Groups as close to "catch-all parties", whose member parties follow the maxim "let us enlarge the Group to control the Parliament, let us get membership in the Group to get the key positions in the House" (Gozi, 2003:1126).

On the other hand, however, what we know is that the political Groups are remarkably cohesive, and that their voting cohesion - as measured via roll-call votes - has actually increased

\footnotetext{
European University Institute, Florence. edoardo.bressanelli@eui.eu
} 
with time, despite the different waves of enlargement of the European Union (Hix et al., 2007). What is more, anedoctal evidence suggests that the national parties are far from indifferent to the policy priorities and the ideological profile of the Group where they seek membership. For instance, the internal divisions of the British Conservatives about membership in the pro-European EPP are well known, and the recent critics of some high-ranking Italian Democrats about their party's alliance with the European Socialists - on the ground that they are democratic, not socialist - show that traditional labels and ideological ties are likely to have some effect upon a party transnational affiliation. Hence, this paper aims to provide a systematic assessment about the nature of the political Groups in the EP, by investigating the factors behind national party membership. In short, it is asked: what drives the national parties to affiliate with a political Groups in the EP? Is the choice of membership driven by pragmatism and office incentives, by policy and ideological affinities, or a mixture of the two?

Substantively, an answer to this question is warranted for at least three reasons. First and foremost, it says a great deal about the nature and the prospects of political parties in the EU. If the Groups are broad aggregations of heterogenous parties, their parliamentary function can be guaranteed by disciplinary mechanisms, or by other institutional devices to build up consensus among their Members. However, being it the case, it is very unlikely that any meaningful transnational party cooperation beyond the parliamentary arena will be achieved. In other words, it is hard to imagine genuine Europarties invested by a representative function, capable to campaign on common programmatic bases across the EU-27. ${ }^{2}$ Second, by investigating the composition of the Groups in the new enlarged EU we assess its capacity to integrate the new Central and Eastern members. Assuming that the Groups in the EU-15 are based on the traditional familles spirituelles, several observers questioned the ideological fit of the new parties from the post-communist states. Thirdly, on a more general level, by studying the policy/ideological profile of the transnational Group we are inevitably confronted with the broad question of the parties programmatic convergence and the (failing?) role of parties as representative agents in modern democracies.

With respect to the existing literature, this work seeks to address the plea for "a systematic attempt at explaining national parties' choice of group membership" (Maurer et al., 2008:246). Until recently, the question of group membership has been only addressed through anecdotal evidence or, focusing on the UK Conservative party, with historical narratives and process tracing (Johansson, 1997; Lynch, Whitaker, 2008; Maurer et al., 2008). In the last few years, a number of

2 The Treaty of Lisbon states: "The functioning of the Union shall be founded on representative democracy" (art. 10.1) and "political parties at European level contribute [...] to expressing the will of the citizens of the Union" (art. 10.4). Furthermore, a proposal to reform the 1976 Electoral Act by MEP Duff suggests the introduction of an additional EU-wide constituency, from which 25 MEPs would be elected on transnational lists. These institutional changes seem to favour the consolidation of the extra-parliamentary parties (see Bardi et al., 2010) 
studies has begun to fill in this lacuna (Klingemann et al., 2007:27-56; Hoyland, Godbout, 2008). The most recent and refined study on the topic, based on expert survey data, is due to McElroy and Benoit who, in presenting their own work, significantly note: "[group membership] exact working remains largely unstudied" (2010:377).

This paper aims at contributing to this growing literature by fitting a predictive model of Group membership for the 140 national parties gaining representation in the 2009 EP issueing their own Euromanifesto. The Euromanifesto data, collected by the Euromanifesto Project (PIREDEU, European University Institute) for the latest EP elections, seem to be particularly apt to address our research goals. Because the Euromanifestos have been collected in 2009, they allow us to include in the analysis all the Member countries of the EU-27 and most of their parties. Moreover, and substantially, the Euromanifestos can be considered as the most authoritative documents, specifically produced for the EU arena by the party central office, where the party defines its general objectives and policy goals.

The rest of this paper is structured as follows. Section II provides background information on the political Groups in the 2009-2014 EP. Section III presents two alternative arguments on Group membership: a first based on ideology or policy compatibility, a second on instrumental incentives and office spoils. Section IV introduces the operationalization of the variables. Section V investigates the factors behind Group membership using a statistical analysis. Finally, Section VI concludes.

\section{Background: the Political Groups in the European Parliament}

In June 2009, the seventh round of direct elections for the European Parliament was held. Shortly afterwards, the political Groups were formally constituted (table 1). The outcome of the elections the first in the EU-27 - was positive for the European People's Party (EPP), reconfirming its leadership in the Chamber with 265 seats. The Socialists could not be fully satisfied by the results which granted them only 184 seats, despite the alliance with the Italian Democrats (hence the new label: Socialists \& Democrats). As in previous legislatures, the third Group in terms of seats was the Alliance of Liberals and Democrats for Europe (ALDE), with 84 members.

Electoral results were rewarding for the Greens - European Free Alliance (EFA), which performed better than expected in several Member countries. On the extreme left, the European United Left (GUE) achieved 35 seats. Two new Groups were also constituted. The British Conservatives together with the Czech Civic Democratic Party and the Polish Law and Justice - left the People's Party and constituted the European Conservatives and Reformists Group (ECR). The British UKIP 
and the Italian Northern League, together with seven other small parties, formed the Europe for Freedom and Democracy (EFD).

Table 1: the political Groups in June 2009

\begin{tabular}{llll}
\hline \multicolumn{1}{c}{ Political Group } & MEPs & Member Parties & Countries \\
\hline European People's Party (EPP) & 265 & 41 & 26 \\
$\begin{array}{l}\text { Progressive Alliance of Socialists and } \\
\text { Democrats }(S \& D)\end{array}$ & 184 & 29 & 27 \\
$\begin{array}{l}\text { Alliance of Liberals and Democrats for Europe } \\
(A L D E)\end{array}$ & 84 & 28 & 18 \\
$\begin{array}{l}\text { The Greens - European Free Alliance } \\
\text { (Greens- } E F A)\end{array}$ & 55 & 19 & 14 \\
$\begin{array}{l}\text { European United Left - Nordic Green Left } \\
\text { (GUE-NGL) }\end{array}$ & 35 & 15 & 14 \\
$\begin{array}{l}\text { European Conservatives and Reformists Group } \\
\text { (ECR) }\end{array}$ & 54 & 8 & 8 \\
$\begin{array}{l}\text { Europe of Freedom and Democracy (EFD) } \\
\text { Non-Attached }\end{array}$ & 30 & 9 & 9 \\
\hline
\end{tabular}

Source: www.europarl.europa.eu

The political Groups are formally reconstituted at the beginning of each parliamentary term. The formal rules of the EP set two conditions for a political Group to be recognised as such. In the new (June 2009) edition of the parliamentary regulations, Rule 30 states: "members may form themselves into groups according to their political affinities" and "a political group shall comprise Members elected in at least one-quarter of the Member States. The minimum number of Members required to form a political group shall be 25 ".

The latter is simply a numerical criterion. A political Group cannot fall below twenty-five Members and has to include at least seven Member Countries. With the enlargements of the EC/EU and the inclusion of more and more members, the numerical criterion has progressively become more demanding, with the purpose of avoiding a too high fragmentation of the parliamentary party system. ${ }^{3}$

The criterion of 'political affinities' is, instead, somewhat more vague and needs to be carefully interpreted. In June 1953 already, the Rules of Procedure of the Coal and Steel Community formally recognised that political Groups could be formed according to "political persuasion". When it was

\footnotetext{
${ }^{3}$ For instance, the 2003 version of the Rules of Procedure $\left(15^{\text {th }}\right.$ ed.) only stated: 'A political group must comprise Members from more than one Member State. The minimum number of Members required to form a political group shall be twenty-three if they come from two Member States, eighteen if they come from three Member States and fourteen if they come from four or more Member States' (Rule 29.2)
} 
first introduced, this requirement was meant to prevent the formation of national groupings. In the early days of European integration, it was broadly felt that the organisation of the Common Assembly in national groupings was fundamentally anti-European. Hence, political persuasion, rather than nationality, was recognised as the the 'glue' sticking the deputies together.

Nevertheless, the formation of such a group as the 'Technical Group for the Defence of Independent Members', constituted in 1979 by the Italian radicals, some communist parties, the Eurosceptic Danes, and Belgian and Irish independents, seems to defy the formal rules. What are the common ideological ties binding together in a Group MEPs officially declaring, in the act of constitution: 'each member of the Group keeps its own political programme, its freedom of speech and of voting both in committees and in the plenary'?

There is indeed one case, in the history of the EP, when a political Group was actually dissolved. It occurred in 1999, when the 'Technical Group for Non-Attached Members - Mixed Group', constituted by deputies of very diverse political backgrounds, from the Italian Radicals to Le Pen's Front National, was dissolved after a ruling of the European Court of Justice. This decision, the first and only one in the sixty years of existence of the EP, was justified on the grounds that the Group explicitly denied in its constitutive declaration the pre-requisite of political affinities.

This decision signals that the requirement of political affinities has a purely negative connotation: in other words, it only indicates when an aggregation of parties is not a political Group. Hence, from a formal reading of the parliamentary Rules of Procedure, a 'political Group' can only be defined as 'a (sufficiently large) set of deputies who do not explicitly refute political affinities among themselves when deciding to form a Group' (Settembri, 2004:168).

\section{Explaining Group Membership: Ideology or Pragmatism?}

As shown above, the formal Rules of the EP do not set too strict criteria for the formation of the political Groups. As the quantitative criterion is achieved, national parties willing to constitute a political Group do not have too worry about 'political affinities', insofar as they do not explicitly deny them. Hence, it shall not be taken for granted that the choice to seek membership, or constitute, a political Group is driven by the ideological or policy compatibility of its member parties. As the formation of a 'Technical Group' shows, national parties might decide to associate with other parties only to enjoy procedural and organizational advantages. As seating in the Chamber as Non-Attached penalizes parties in several important respects, ${ }^{4}$ being in a political

\footnotetext{
${ }^{4}$ Non-attached members do not have voting rights in the Conference of the Presidents, the Parliament executive organ; they are allocated a residual fraction of the speaking time in the plenary; they are rarely allocated important reports and, as to symbolically represent their minor role, they sit at the very back of the hemycycle.
} 
Groups might be convenient in terms of influence and ressources, but might have little - if anything - to do with ideology.

In what follows, I will present two different arguments about political Group membership. For a first argument, what counts most is the ideological or policy affinity with the other members. National parties will choose the political Group that best matches their ideological position or policy preferences. For a second argument, national parties are mostly guided by the pursuit of office goals and pragmatic objectives. The institutional rules of the EP grant more power and ressources to the large political Groups. National parties can hardly attain any office goals if not as members of a political Group, and large governing parties will have strong incentives to enter the EPP or the S\&D. Both arguments are presented in more details below.

\section{Ideology or Programmatic Affinities}

The traditional explanation for Group membership is based on the ideological compatibility of the member parties within each political Group, granted by the common cleavages upon which the West European party systems originated. Thomassen and Schmitt have repeteadly emphasized in their works that a EU party system can only be 'feasible' if the major lines of political conflict in Europe do not coincide with the national borders but, rather, cross-cut national distinctions $(2004,2009)$. The formation of the political Groups is traditionally described by a reading of European politics based upon a few fundamental social cleavages, which had been 'activated' and interpreted by political actors in a roughly similar fashion throughout Western Europe. The social cleavages between agriculture and labour, the church and the state, the centre and the periphery, the industrial workers and the owners of the capital (Lipset, Rokkan, 1967) - 'produced' competing political parties, which could be grouped in distinct party families (and political Groups) according to the social groups they represent and the basic ideological principles they follow.

A 'party family' explanation of national parties' transnational affilation is to be found in several early studies of the EU party system and its units (Van Oudenhove, 1965; Marquand, 1978; Von Beyme, 1985). Additionally, several recent scholarly contributions point to the enduring validity of ideology or policy-based arguments. For instance, Klingemann and colleagues, basing their analysis on national election manifestos, test whether the political Groups "have a strong basis in the old party families and hence are grounded in their policies and ideologies" (2007:28). From the results of a discriminant analysis, they conclude that: "the success of our classifications demonstrates the programmatic coherence of the European groupings" (39).

A similar conclusion is also reached by the study of the MEPs' ideal points, as estimated from the 
scaling of roll-call votes. As Hix and colleagues strongly put it: "politics in the European Parliament is very much like politics in other democratic parliaments, dominated by left-right positions and driven by the traditional party families of domestic European politics" (2007:181). The voting behaviour of the MEPs would be largely determined by domestic party preferences, and the relatively high voting cohesion of the political Groups would be, at least partly, explained by the similar ideological preferences of their members.

Finally, drawing from their own expert survey data, McElroy and Benoit test the hypothesis that "the fundamental driving force behind national party affiliation in EP party groups is policy congruence: national political parties will seek membership in EP party groups whose policy platforms are closest to their own, on their most important national policy dimensions" (2010:377). The results of their sophisticated empirical analysis confirm their expectation, leading them to conclude that "Party groups at the transnational level not only operate in a similar policy space as do national parties, but also tend to be formed mainly as coalitions of parties that are like-minded on matters of policy" (396). Although McElroy and Benoit explicitly challenge the validity of 'party family' explanations, the observational implications of their study do not appear too different from Klingemann's work, rooted in a more traditional framework. ${ }^{5}$

\section{Pragmatism and Office Spoils}

An alternative argument posits that the Groups are broad coalitions of national parties, where the programmatic convergence - not to say the identity - of the members is very loose. As Fabbrini puts it: "Groups have progressively become mere coalitions of national parties with the objective to coordinate the national representatives on specific policies. Differences within each of the Groups are so starking that the label of 'party' is, in most of the cases, wholly instrumental" (2003:9-10). A similar picture is also made by the then Secretary-General of the European People's Party: "moderates on the Left/Centre-Left are progressively gathering together under the umbrella of the PES, and those of the Right/Centre-Right under that of the EPP. [...] On the agenda is the development of people's parties that are essentially free of ideology (Jansen, 2006:55).

\footnotetext{
5 McElroy and Benoit's critique on the use of the concept of 'party family' to study political Group affiliation is based on three aspects. First, it provides a "static" picture, while transnational affiliation is a dynamic process. Second, the 'party family' concept is difficult to apply to Central and Eastern Europe and to single-issue parties. Third, 'party family' categories provide low information, being categorical in nature (2010:382-3). On a conceptual level, the first point seems disputable. 'Party families' do change over time. For instance, the Socialist family of the Sixties, traditionally Marxist, is very different from the Socialist family of today, embracing a social-market economy. Empirically, the third point raised by McElroy and Benoit seems to capture a mode of operationalizing 'party family' based on party origin or sociology. An alternative operalization, however critizable on its own grounds, is indeed based on "the congruence of the policies and/or ideologies that are professed or even pursued by the parties" as estimated from expert surveys, voting behaviour, manifestos and other data (Mair, Mudde, 1998:217).
} 
The roots of this development are located in the broader context of the ideological/policy convergence of political parties (Volkens, 2006) and the affirmation of the cartel party model (Katz, Mair, 1995). Furthermore, rationalist-choice studies place their focus on the important role played by the structure of incentives which the national parties are confronted with when they enter the Parliament (Gozi, 2003; Maurer et al., 2008). In extreme synthesis, it is argued that the larger the Group is, the more financial and administrative ressources, key committees and legislative reports obtains and it is able to distribute among its members.

Indeed, both the supply-side - the political Groups - and the demand-side - the candidate parties face strong instrumental or self-interested incentives to, respectively, include more members and seeking membership in the existing Groups. For the latter, a 'marriage of convenience' is rewarding both in terms of office positions and influence in the European Parliament. By joining an existing Group, parties enjoy the advantage of having a large bureaucratic apparatus at their disposal, with an experienced staff and substantial financial ressources they can draw on. In particular, it is crucially important for the governing parties - "parties with a majoritarian vocation" (Fabbrini, 2006:9) - to get membership in either the EPP or the S\&D: several rules in the EP reward the larger, penalizing the smaller Groups.

To start with, votes in the Conference of Presidents are weighted for the number of MEPs, thus favouring the largest Groups in all important decisions over the EP legislative planning and organization (Rule 24). Furthermore, the D'Hondt method is generally employed for the distribution of office positions. Albeit in the family of proportional formulas, it tends to better reward the largest parties. Hence, when committee or inter-parliamentary delegation chairmanships are distributed, all the most coveted positions are assigned to the largest Groups. As illustrated by Corbett et al.: "in 2004, for example, the EPP-ED group had the right to the first, third, fifth, seventh, ninth, twelfth, seventeenth, nineteenth ad twenty-first choice, the Socialists to the second, fourth, eighth, tenth, sixteenth, twentieth and twenty-second choices [...] the UEN to the twenty-fourth choice" (2007:130).

Finally, the distribution of legislative reports in Committees is, also, generally based on a points system favouring the largest political Groups. It has been shown that "the auction-like points system means that only the PES and the EPP can normally afford the most expensive reports" and that thelargest political groups are "over-represented" in the share of reports they get (Mamadouh, Raunio, 2003:346-347). Although not all the committees apply the D'Hondt system, and other considerations sometimes matter (such as a the Member's seniority or his/her technical competences), only two minor Committees - Petition and Budgetary Control - do not apply any 
points system at all (European Parliament, 2009).

On the other hand, the political Groups have equally powerful incentives to expand their membership, without being too strict on ideological compatibility. According to the Regulation on political parties at European level, ${ }^{6}$ the quota of financial ressources the extra-parliamentary parties get is strictly propotional to their number of seats it has in the Parliament. ${ }^{7}$ Failure to include large national parties might then lead to a relevant drain in ressources.

Moreover, financial advantages are not only indirect. The parameters for the distribution of ressources among the political Groups are based on both their size (the sheer number of Members) and their diversity (the number of Countries). Consequently, the larger and more diverse the Group is, the more staff and financial ressources it will get. Again, failure to include large parties might substantially weaken a Group vis-a-vis its competitors in the EP.

The instrumental incentives for Group membership are likely to be particularly strong for 'new' parties, which have been only marginally exposed to the practices of transnational party cooperation and, as in the case of the parties of the post-communist region, do not often represent clear-cut social cleavages as their Western counterparts, at least historically, did. ${ }^{8}$ Indeed, in their study on Group affiliation, based on the MEPs' speeches in the plenary, Hoyland and Godbout conclude: "the parties from the new member states were all but guided by ideology or similarity in belief system with parties from the old member states in their choice of party group affiliation" (2008:2). Whereas in their study on party families in Eastern Europe, Hlousek and Kopecek note that "many parties aspire to membership in this or that established supranational party structure for pragmatic tactical reasons rather than political self-identification: it is simply advantageous for them" (2010:11) pointing - among others - to the manifest cases of the SMER Party in Slovakia and the Freedom Union in Poland. ${ }^{9}$

\footnotetext{
${ }^{6}$ Regulation (EC) No 2004/2003 of the European Parliament and of the Council of 4 November 2003 on the regulations governing political parties at European level and the rules regarding their funding, Official Journal, L 297, 15.11.2003, p. 1-4 and Regulation (EC) No 1524/2007 of the European Parliament and of the Council of 18 December 2007 amending Regulation (EC) No 2004/2003, Official Journal, L 343, 27.12.2007, p. 5-8.

${ }^{7}$ Art. 10 of Reg. 2004/2003 reads: "Available appropriations shall be distributed annually as follows among the political parties at European level which have obtained a positive decision on their application for funding as referred to in Article 4: (a) $15 \%$ shall be distributed in equal shares; (b) $85 \%$ shall be distributed among those which have elected members in the European Parliament, in proportion to the number of elected members"

${ }^{8}$ Moreover, for Central and Eastern Europe parties, transnational affiliation also represented an important source of legitimacy 'at home'. For parties without long political biographies, membership in a particulat Europarty could be a card to be played against competitors. When several parties are competing to occupy the same ideological space, Europarty membership could offer a significant competitive advantage.

${ }^{9}$ SMER was granted provisional membership of the PES only in 2005 and it was suspended from October 2006 to February 2008, having entered a government coalition with the extreme nationalists of the SNS party.
} 
Additionally, the relevance of pragmatic incentives for Group membership has been well illustrated for the case of the British Conservative Party, whose alliance with the EPP has been defined as a "loveless marriage" (Lynch, Whitaker, 2008) or a "marriage of convenience" (Maurer et al., 2008). Despite some differences on socioeconomic policies and, more manifestly, on European Integration, the Tories have been members of the EPP - European Democrats from 1994 to 2009. Searching for the motives behind the alliance, Johansson reports some revealing comments by the Tory MEPs: the alliance "would give the Conservative far more clout"; "influence is magnified by being part of a larger family"; if isolated the Tories would be "without influence" (1997:146-148).

A less studied case is that of the Italian Democrats. The party was born in 2007 as a merger of the former Communists and left-wing Christian-Democrats, but its MEPs continued to sit in two different Groups, the PES and the ALDE, in the 2004-2009 Parliament. The question of which political Group the PD should choose in the 2009-2014 Parliament had been very divisive within the party and all the available options were considered. As the discussion in the party unfolded, however, both the idea to create a new 'federalist' Group and to join the Non-Attached were ruled out. As several party members declared, both alternatives would have implied a "loss of influence", leaving "the party isolated in Europe" (interviews, 25-01-10; 06-02-10). The PD, finally, chose the Socialists, constituting the new Socialists and Democrats alliance - where the Democrats are the Italian delegation only.

\section{Data and Methods}

The data used to estimate the ideology or policy position of the national parties, and empirically test the argument that Group membership is driven by the ideological compatibility of their members, are the Euromanifestos issued by the national parties for the 2009 European Parliament elections. Euromanifestos were collected and coded by the the Euromanifesto Project (EMP), now part of the broader European Election Study 2009 (www.piredeu.eu). The theoreotical and methodological foundations of the EMP lie in the Comparative Manifestos Project (see, inter alia, Budge et al., 2001). In order to transform the Euromanifesto text into numbers, each unit of analysis - a 'quasisentence', representing the verbal expression of one political idea or issue - is placed under a policy category defined by the coding dictionary. In the 2009 version of the EMP, categories have been recasted in a hierarchical manner. Each category first identifies the policy issue (ie. 'state involvement in the economy'), only then the coder decides whether the statement has positive or negative connotation (Braun et al., 2010:17-18). Hence, pure 'valence' issues are coded in a first step. In a second, the party position with respect to each policy category is captured. 
As in the CMP, individual policy categories can be aggregated to compute policy scales where political parties can be convenientely located. Two policy dimensions are commonly regarded as sufficient to provide a parsimonious, yet accurate, representation of the ideological space occupied by the political Groups: a left-right and a sovereignty-integration dimension (Hix et al., 2007:161165). The computation of the former is based on a slightly modified version of the original CMP scale, including new sub-categories (Budge et al., 2001:22-25, Braun et al., 2010:56). The latter is, instead, computed by subtracting positive to negative categories on European institutions and policies (Braun et al., 2010:56).

In order to provide a more fine-grained representation of party positions, and to make a fuller use of the information contained in the Euromanifestos, four additional relevant scales have also been computed. ${ }^{10}$ Drawing on Lowe et al. (2008) on the computation of specific policy scales with manifesto data, and checking the covariation of categories with confirmatory factor analysis, we computed policy scales on market economy, welfare expansion, environment and liberalconservatism. ${ }^{11}$

Furthermore, to empirically test the argument that Group membership is driven by office rewards and pragmatism, we computed the variable size as the vote share of the party in the closest national election ahead the 2009 elections to the European Parliament, obtaining electoral figures from http://www.parties-and-elections.de (see McElroy, Benoit, 2010:388). What we are able to test is, specifically, whether large parties ('parties with majoritarian vocation') are more likely to enter the largest political Groups, ceteris paribus.

Our dependent variable is constituted by seven categories - the seven political Groups formed at the beginning of the 2009-2014 European Parliament (table 2). Because of the qualitative, categorical nature of the dependent variable, we fitted a multinomial logit model on the 140 observations (national parties) for which we have full non-missing data. ${ }^{12}$ The multinomial logit model is a simple extension of the logit model, presenting a series of binary comparisons between the outcome categories of the dependent variable. Hence, when J categories constitute the outcome, J - 1 binary logits need to be estimated.

10 The selection of this scales is based on two criteria. First, such scales are included and, as a consequence, regarded as important, in most of the studies on Europarties positions and differences (Klingemann et al., 2007:29-56; McElroy, Benoit, 2007; Trechsel, Mair, 2009). Second, a descriptive analysis of the Euromanifestos reveals that the selected scales capture the most salient issues for the parties.

11 Scales on market economy, environment and liberal-conservatism are 'confrontational', that is computed by subtrating opposing categories. The scale on welfare is 'additive' and is computed as the sum of pro-welfare categories. On 'confrontational' vs 'additive' scales, Klingemann et al., 2007:114.

12 Very few parties do not issue a proper Euromanifesto. When this is the case, the EMP has searched for a a substitute, such as the European 'chapter' of the national election platform. For the analysis, leaders declarations and short flyers have not been considered to be proper substitutes. Being very succint documents, they return extreme and implausible estimates (see Gabel, Huber, 2000:100) 
Table 2: Dependent variable: non-missing observations

\begin{tabular}{llll}
\hline Political Group & Freq. & Percent & Cum. Percent \\
\hline EPP & 40 & 28.57 & 27.97 \\
S\&D & 26 & 18.57 & 47.14 \\
ALDE & 27 & 19.29 & 66.43 \\
Greens-EFA & 18 & 12.86 & 79.29 \\
GUE-NGL & 15 & 10.71 & 90.00 \\
ECR & 7 & 5 & 95.00 \\
EFD & 7 & 5 & 100 \\
\hline \multicolumn{1}{c}{$\boldsymbol{T o t}$} & 140 & 100 & \\
\hline
\end{tabular}

Logit models predict the probability of a certain outcome occurring - in our case, the choice of group $\mathrm{j}$ over group $\mathrm{j}_{\mathrm{i}}$ - given the values of the explanatory variables. The regression coefficients, estimated by maximum-likelihood, indicate whether the explanatory variables increase or decrease the probability of the outcome occurring.

Because of non-linearity, we follow a standard practice by reporting odds ratios $\left(\mathrm{e}^{\beta}\right)$, rather than the $\beta$ coefficients. Odds ratios provide a more intuitive interpretation of the effect of each regressor: for a unit change in $x_{i}$, the odds of $y=1$ change by a factor of $e^{\beta}$, holding all other variables constant. Odds ratios with values between 0 and 1 point to a negative effect (the probability of choosing group $\mathrm{j}$ over group $\mathrm{j}_{\mathrm{i}}$, decreases) whereas odds ratios greater than 1 indicate a positive effect.

Multinomial logit models can also be usefully employed as classification tools. The parameters of the model are estimated as to maximise the probability of observing the selected sample. Predictions for each observations are then computed, and probabilities assigned to each national party to fall in each outcome category. To ease interpretation, a table featuring observed vs predicted probabilities is regarded as a most effective way to synthetically display the many comparisons involved in multinomial logit (Long, Freese, 2006:157-158).

There are two main aspects - beside the data - distinguishing this analysis from similar exercises in the literature. Differently from Klingemann et al. (2007:29-51), we select our scales deductively, rather than computing linear combinations from the data and then provide an ex post interpretation of their meaning. Indeed, although multinomial logit and discriminant analysis can both be used to classify observations into groups, the latter presents the advantage of selecting the variables of interest out of theoretical considerations, rather than letting the data 'speak for themselves'.

Differently from McElroy and Benoit (2010), we use multinomial, rather than conditional logit. The 
main difference between the two models is that the latter also incorporates information on 'choicelevel' variables. In other words, not only characteristics of the individual-level, but also features of the choice-level variable (the political Groups) inform the model. Despite its attractiveness, conditional logit has not been used here because, as to get information on the ideological position of the Groups, we would have needed to rely on the Europarty Euromanifestos. However, not only they are considerably shorter than the national party manifestos, but they are also commonly regarded as lacking substantive policy content (Roa Bastos, 2009).

In what follows, we make three different estimates of Group membership. First, we build a simple model (Model 1) where only the left-right and the anti-pro EU integration scales are entered. These variables should suffice to capture the fundamental ideological differences between the political Groups, if the Groups are grounded on the common ideologies of their members. In Model 2, we further include the variable size, as to capture the pragmatic and office-driven motivations of the parties. Finally, Model 3 takes into account the complexity of the ideological profile of the political Groups including, as predictors, further dimensions on market economy, welfare expansion, liberalconservatism and environment. This last model is used to compute the predicted probabilities for each national party to be member of each political Group.

\section{Results}

Model1 reveals that ideology is a strong predictor of Group membership in the EU-27. A unit change in the left-right scale makes a national party more likely by a factor of 1.11 to join the EPP rather than than the $S \& D(p<.01)$ and less likely by a factor of $.93(p<.01)$ to enter the $S \& D$ rather than the ALDE (chosen as comparison category). Coefficients for the variable left-right are also significant when the ALDE is compared with the Groups located on its left: a unit move towards the right makes a party less likely to enter the ALDE by a factor of .95 vis-a-vis the Greens and by a factor of .84 with respect to the GUE $(\mathrm{p}<.01)$. Furthermore, there is a large and highly significant coefficient when the S\&D - EPP comparison is made.

By contrast, the left-right dimension weakly distinguishes the ALDE from the Groups located on its right. In the binary comparisons with the ECR and the EFD, the anti-pro integration dimension is far more important. Both Groups are considerably less supportive of the EU integration process than the ALDE. Ceteris paribus, a unit increase in the support for integration makes a national party less likely to join the ECR by a factor of .84 and the EFD by a factor of .7 (both significant at .01). Furthermore, it shall be noted that the ALDE and the GUE-NGL are also clearly distinguished in 
their support for EU integration.

However, ideology is not sufficient to fully account for the composition of the political Groups. Indeed, in Model 2, the variable size is also highly significant $(\mathrm{p}<.01)$ for the ALDE/EPP, the ALDE /S\&D and the ALDE/Greens comparisons. The odds-ratios are positive in the former two cases: a unit increase in size, controlling for the party position, makes a national party 1.08 and 1.12 times more likely to join, respectively, the EPP and the S\&D rather than the ALDE. Moreover, it is worth noticing that size has an effect also in the 'choice' between medium-size and small political Groups. Controlling for ideological position, as national parties get bigger, they are more likely to join the ALDE rather than the Greens.

A likelihood ratio test has been made between model 1 (a reduced model) and model 2 to formally test if the variable size makes a relevant contribution. The results confirm that size improves significantly $(\mathrm{p}<.01)$ the fit of the model. Indeed, the pseudo $\mathrm{R}^{2}$ increases by about eleven percent, moving from .26 in Model 1 to .37 in Model 2.

Model 1

\begin{tabular}{|c|c|c|c|c|c|c|c|}
\hline & $\begin{array}{c}\text { ALDE } \\
/ \\
\text { EPP }\end{array}$ & $\begin{array}{l}\text { ALDE } \\
/ \\
\text { S\&D }\end{array}$ & $\begin{array}{c}\text { ALDE } \\
/ \\
\text { Greens } \\
\end{array}$ & $\begin{array}{c}\text { ALDE } \\
/ \\
\text { GUE }\end{array}$ & $\begin{array}{c}\text { ALDE } \\
/ \\
\text { ECR }\end{array}$ & $\begin{array}{c}\text { ALDE } \\
/ \\
\text { EFD }\end{array}$ & $\begin{array}{l}\text { S\&D } \\
/ \\
\text { EPP }\end{array}$ \\
\hline Left-Right & $\begin{array}{l}1.03 \\
(.02)\end{array}$ & $\begin{array}{l}.93 * * * \\
(.03)\end{array}$ & $\begin{array}{l}.95^{*} \\
(.03)\end{array}$ & $\begin{array}{l}.84 * * * \\
(.04)\end{array}$ & $\begin{array}{l}1.07 * \\
(.04)\end{array}$ & $\begin{array}{l}1.01 \\
(.05)\end{array}$ & $\begin{array}{l}1.11 * * * \\
(.03)\end{array}$ \\
\hline Anti-Pro EU & $\begin{array}{l}1.00 \\
(.03)\end{array}$ & $\begin{array}{l}.93 \\
(.04)\end{array}$ & $\begin{array}{l}.92 * \\
(.04)\end{array}$ & $\begin{array}{l}.77 * * * \\
(.05)\end{array}$ & $\begin{array}{l}.84 * * * \\
(.05)\end{array}$ & $\begin{array}{l}.7 * * * \\
(.05)\end{array}$ & $\begin{array}{l}1.07 * \\
(.04)\end{array}$ \\
\hline
\end{tabular}

${ }^{*} p<.1 * * p<.05 * * * p<.01$ Standard Errors in parentheses

$\mathrm{n}=140 ;$ Log-likelihood $=-185.3 ;$ Pseudo $\mathrm{R}^{2}=.26$

Model2

\begin{tabular}{|c|c|c|c|c|c|c|c|}
\hline & $\begin{array}{l}\text { ALDE } \\
/ \\
\text { EPP }\end{array}$ & $\begin{array}{l}\text { ALDE } \\
/ \\
\text { S\&D }\end{array}$ & $\begin{array}{c}\text { ALDE } \\
/ \\
\text { Greens }\end{array}$ & $\begin{array}{c}\text { ALDE } \\
/ \\
\text { GUE }\end{array}$ & $\begin{array}{c}\text { ALDE } \\
/ \\
\text { ECR }\end{array}$ & $\begin{array}{c}\text { ALDE } \\
/ \\
\text { EFD }\end{array}$ & $\begin{array}{c}\mathrm{S} \& \mathrm{D} \\
/ \\
\mathrm{EPP}\end{array}$ \\
\hline Left-Right & $\begin{array}{l}1.04 * \\
(.02)\end{array}$ & $\begin{array}{l}.93 * * \\
(.03)\end{array}$ & $\begin{array}{l}.94 * * \\
(.03)\end{array}$ & $\begin{array}{l}.85 * * * \\
(.04)\end{array}$ & $\begin{array}{l}1.08 * * \\
(.04)\end{array}$ & $\begin{array}{l}1.01 \\
(.05)\end{array}$ & $\begin{array}{l}1.13 * * * \\
(.03)\end{array}$ \\
\hline Anti-Pro EU & $\begin{array}{l}.97 \\
(.03)\end{array}$ & $\begin{array}{l}.92 \\
(.04)\end{array}$ & $\begin{array}{l}.92 * \\
(.05)\end{array}$ & $\begin{array}{l}.77 * * * \\
(.05)\end{array}$ & $\begin{array}{l}.82 * * * \\
(.05)\end{array}$ & $\begin{array}{l}.70 * * * \\
(.06)\end{array}$ & $\begin{array}{l}1.07 \\
(.05)\end{array}$ \\
\hline Size & $\begin{array}{l}1.08^{* * * *} \\
(.03)\end{array}$ & $\begin{array}{l}1.12 * * * \\
(.03)\end{array}$ & $\begin{array}{l}.81^{* * *} \\
(.06)\end{array}$ & $\begin{array}{l}.99 \\
(.06)\end{array}$ & $\begin{array}{l}1.07 * \\
(.04)\end{array}$ & $\begin{array}{l}1.00 \\
(.08)\end{array}$ & $\begin{array}{l}.96^{*} \\
(.02)\end{array}$ \\
\hline
\end{tabular}

${ }^{*} p<.1 * * p<.05 * * * p<.01$ Standard Errors in parentheses

$\mathrm{n}=140 ;$ Log-likelihood $=-158.11 ;$ Pseudo $\mathrm{R}^{2}=.37$ 
In order to better capture the specific effect of left-right on Group membership, it is useful to graph its effect by keeping the other variables constant at some specified value. Hence, in Graph 1, we show the probability for a national party to join each political Group as its position on the left-right dimension is allowed to vary and the other variables - its position on European integration and size - are kept constant at their mean value.

The key to interpret the graph is to look at the differences between shaded areas. Moving up from the $\mathrm{x}$-axis, the dark grey area represents the predicted probabilities of joining the S\&D. Together with the bordering shaded area - coloured in lighter grey - they represent the summed probability that a national party will join either the S\&D or the ALDE - as its position on left-right varies. Finally, the difference between the two areas can be read as the probability to enter the ALDE Group.

As it can clearly be seen, as a party moves from left to right its options for transnational membership change dramatically. The more right-wing a party is, the bigger its chances to join the EPP or the ECR. On the other hand, the more left-wing a party is, the more likely it is to associate with the GUE or the S\&D. Towards the centre of the left-right spectrum, the ALDE and the EPP become the most likely choice. Overall, differences in the left-right position of the national parties clearly matter in the choice between the political Groups. When all the national parties are pooled together, we obtain a rather traditional representation of the EP ideological space in the EU-27 with the political Groups neatly differentiated for their position on the left-right dimension.

Graph 1: Predicted probabily plot: effect of left-right on Group membership

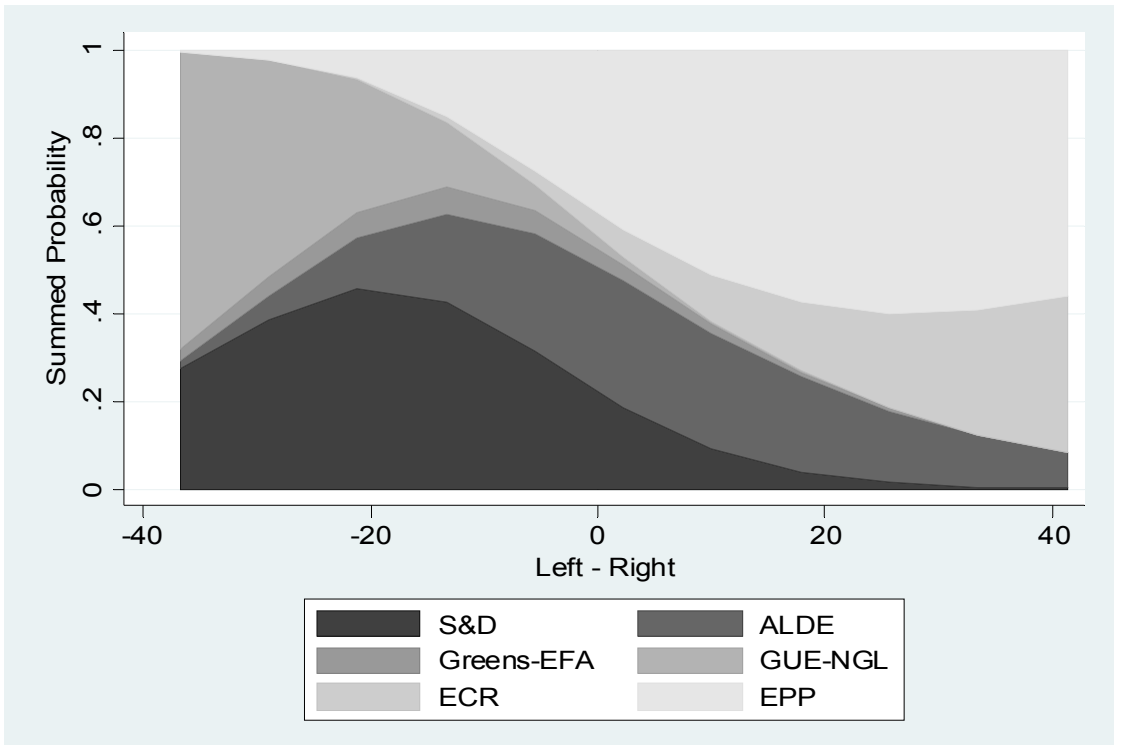

Note: $n=140$. Other variables kept at their mean-values 
Based again on Model 2, Graph 2 below shows, instead, the effect of the variable size, keeping the other independent variables at their mean-values. The graph compares the probability of joining a large group (either the S\&D or the EPP) vs a middle-size group (the ALDE) as the national parties grow in size. In both cases, it can be observed that the Liberals seem to be a less attractive option for large national parties. Differently said, as far as a party gets supported by less than ten percent of the voters, ceteris paribus it is more likely to join the Liberals. In contrast, as the 10 percent 'threshold' is overcome, the EPP or the S\&D appear to be more rewarding alternatives.

\section{Graph 2: Variations in Size and Effect on Group Membership}
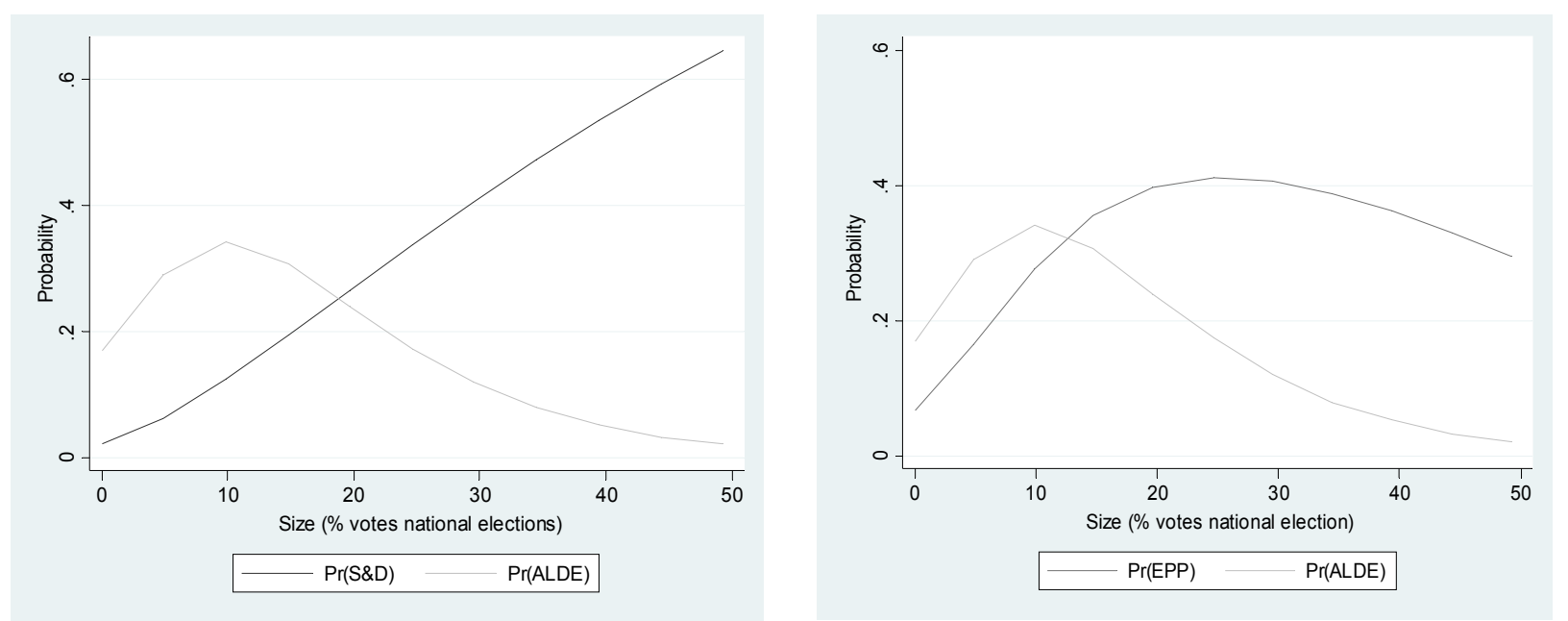

Note: $n=140$. Other variables kept at their mean-values

Looking at the estimates of Model 1 and Model 2, both ideology and pragmatism seem to matter for national parties' Group membership. True, size accounts for a lesser proportion of the explained variance, but this is hardly the final word on the matter. However, before tackling this point further in the following section, it worth focusing on Western and Eastern Europe separately. Two separate models have been run for the two sub-groups. Due to the low number of parties in the smaller political Groups in Eastern Europe, the number of outcome categories has been reduced to three. In other words, we only estimate the probabilities of joining the S\&D, the ALDE and the EPP. Below, Graph 3 displays the predicted probabilities, as left-right varies and the other predictors are kept at their mean values. 
Graph 3: Comparing left-right in the West and in the East of Europe
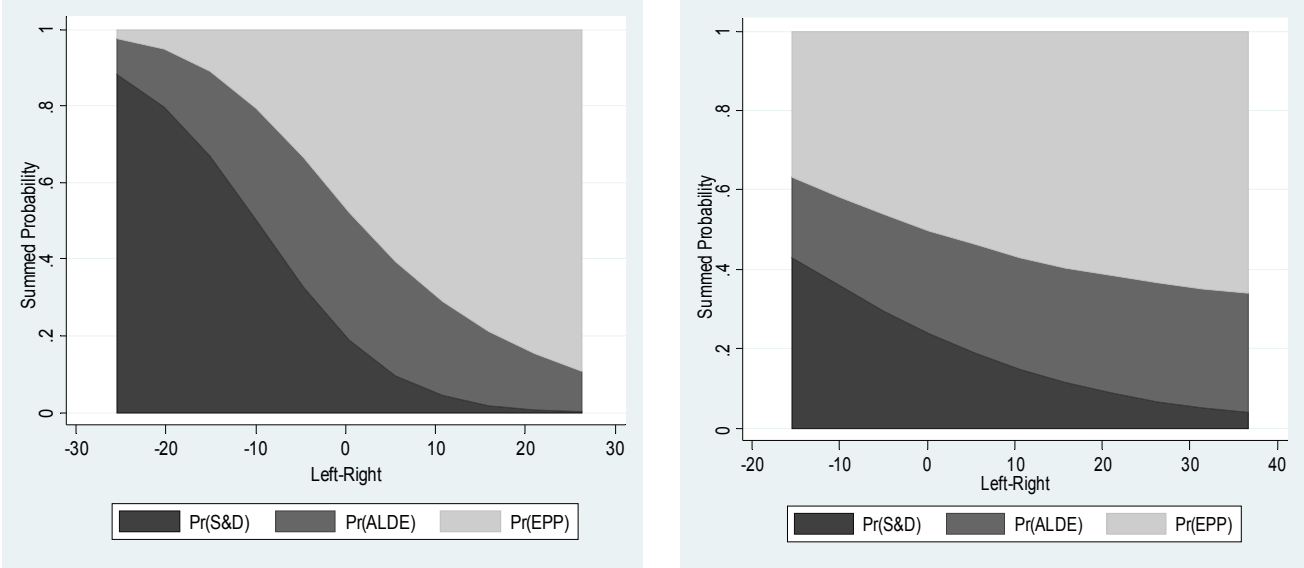

Note: $n($ Old $)=56 ; n(N e w)=37$. Other variables kept at their mean-values

In general, the effect of left-right appears to be somewhat different in the two macro-regions. In the 'Old' Europe ideological differences between the three 'core' political Groups seem more starking. As national parties move to the left, they are more and more likely to join the S\&D Group. On the other hand, as they approach the right-pole of the spectrum, the probability of entering the People's Party becomes very large. In-between the two largest groups there is a clear space for the Liberals, which are more likely to be chosen by the parties located towards the centre of the left-right spectrum.

In the 'New' Europe, by contrast, differences are not as clear. True, the pattern is broadly similar: on the left, the S\&D is the most likely option; on the right, the EPP becomes the preferred alternative. However, it is only broadly so: the area occupied by the EPP is much broader than in Western Europe, and parties located on the left (by comparative standards) are also quite likely members of the People's Party. The picture is more 'normal' on the right - where the likelihood to enter the S\&D becomes very small.

Overall, left-right does not appear to be a very powerful predictor of Group membership for the parties of post-communist Europe. At a minimum, it does not differentiate among the political Groups as neatly as it does for Western Europe. This point - crucial to assess the integration of the New Members in the enlarged Europe - begs further investigation. In the following section, I will specifically assess, informing a model only with the national party positions on some important policy scales, how many and which parties do not fit in the transnational groupings. 
Model 3 includes four additional policy scales beside left-right and EU integration: market economy, welfare expansion, liberal-conservatism and environment. Such specification improves the fit of the Model (pseudo- $\mathrm{R}^{2}$ ) to 0.52. Its interpretation involves many comparisons and it is not easy. The effect of the general left-right scale is mostly captured by the other policy dimensions. For instance, differences between the S\&D and the ALDE, as well as between the S\&D and the EPP, are due to the members' positions on the economy. Those national parties supporting a more active role of the State in the economy are more likely to seek membership in the S\&D, while the EPP members are the strongest supporters of a laissez-faire economic policy. In other cases, the effect of the general left-right scale is captured by liberal-conservatism. Hence, in the comparison between the ALDE and the EPP the scale on 'new politics' is strongly significant $(\mathrm{p}<.01)$ and indicates that the more conservative parties are more likely to get membership in the EPP.

Model 3

\begin{tabular}{|c|c|c|c|c|c|c|c|}
\hline & $\begin{array}{c}\text { ALDE } \\
/ \\
\text { EPP }\end{array}$ & $\begin{array}{c}\text { ALDE } \\
/ \\
\text { S\&D }\end{array}$ & $\begin{array}{c}\text { ALDE } \\
/ \\
\text { Greens }\end{array}$ & $\begin{array}{c}\text { ALDE } \\
/ \\
\text { GUE }\end{array}$ & $\begin{array}{c}\text { ALDE } \\
/ \\
\text { ECR }\end{array}$ & $\begin{array}{c}\text { ALDE } \\
/ \\
\text { EFD }\end{array}$ & $\begin{array}{l}\text { S\&D } \\
/ \\
\text { EPP }\end{array}$ \\
\hline Left-Right & $\begin{array}{l}1.01 \\
(.03)\end{array}$ & $\begin{array}{l}.97 \\
(.04)\end{array}$ & $\begin{array}{l}.91 * \\
(.05)\end{array}$ & $\begin{array}{l}.9 \\
(.06)\end{array}$ & $\begin{array}{l}1 \\
(.06)\end{array}$ & $\begin{array}{l}1.06 \\
(.08)\end{array}$ & $\begin{array}{l}1.04 \\
(.04)\end{array}$ \\
\hline Anti-Pro EU & $\begin{array}{l}1.04 \\
(.04)\end{array}$ & $\begin{array}{l}.96 \\
(.05)\end{array}$ & $\begin{array}{l}.96 \\
(.07)\end{array}$ & $\begin{array}{l}.73 * * * \\
(.08)\end{array}$ & $\begin{array}{l}.86^{*} \\
(.07)\end{array}$ & $\begin{array}{l}.73 * * * \\
(.07)\end{array}$ & $\begin{array}{l}1.09 \\
(.06)\end{array}$ \\
\hline Environment & $\begin{array}{l}.95 \\
(.06)\end{array}$ & $\begin{array}{l}.93 \\
(.06)\end{array}$ & $\begin{array}{l}1.12 * * \\
(.07)\end{array}$ & $\begin{array}{l}.85 \\
(.1)\end{array}$ & $\begin{array}{l}.72 * * \\
(.11)\end{array}$ & $\begin{array}{l}.66^{* *} \\
(.12)\end{array}$ & $\begin{array}{l}1.02 \\
(.08)\end{array}$ \\
\hline $\begin{array}{l}\text { Liberal- } \\
\text { Conservatism }\end{array}$ & $\begin{array}{l}1.17 * * * \\
(.06)\end{array}$ & $\begin{array}{l}1.06 \\
(.06)\end{array}$ & $\begin{array}{l}.67 * * * \\
(.08)\end{array}$ & $\begin{array}{l}.78^{* *} \\
(.09)\end{array}$ & $\begin{array}{l}1.15 \\
(.11)\end{array}$ & $\begin{array}{l}.96 \\
(.08)\end{array}$ & $\begin{array}{l}1.10 \\
(.06)\end{array}$ \\
\hline $\begin{array}{l}\text { Market } \\
\text { Economy }\end{array}$ & $\begin{array}{l}1.08 \\
(.13)\end{array}$ & $\begin{array}{l}.6^{* * *} \\
(.1)\end{array}$ & $\begin{array}{l}.84 \\
(.14)\end{array}$ & $\begin{array}{l}.46^{* * * *} \\
(.13)\end{array}$ & $\begin{array}{l}1.17 \\
(.25)\end{array}$ & $\begin{array}{l}.60 \\
(.2)\end{array}$ & $\begin{array}{l}1.80^{* * *} \\
(.3)\end{array}$ \\
\hline $\begin{array}{l}\text { Welfare } \\
\text { Expansion }\end{array}$ & $\begin{array}{l}1.01 \\
(.06)\end{array}$ & $\begin{array}{l}1.09 \\
(.07)\end{array}$ & $\begin{array}{l}1 \\
(.08)\end{array}$ & $\begin{array}{l}1.08 \\
(.1)\end{array}$ & $\begin{array}{l}.56^{* *} \\
(.15)\end{array}$ & $\begin{array}{l}.98 \\
(.12)\end{array}$ & $\begin{array}{l}.93 \\
(.06)\end{array}$ \\
\hline
\end{tabular}

$* p<.1 * * p<.05 * * * p<.01$

$\mathrm{n}=140$

Log-likelihood $=-120.94$

Pseudo $\mathrm{R}^{2}=52$

In order to simplify the task of interpreting Model 3, we also estimated the predicted probabilities for each national party to join the seven political Groups, based on the location of the national parties on the six policy dimensions. By convention (see Budge et al., 1987:400-401), the highest 
probability is taken as the predicted outcome category. Then, each prediction is confronted with the actual Group where the party is member, calculating a probability ratio as correctly predicted / observed cases.

Overall, the model correctly predicts the transnational affiliation of 100 out of 140 parties, that is the $71,4 \%$. In other words, by only knowing their position on six policy scales, we have been able to classify more than two parties out of three in the correct political Group. ${ }^{13}$ This finding nicely mirrors the comparable exercises in the literature: Klingemann et al. (2007) place the $68 \%$ of their parties $(n=133)$ in the correct grouping, while Benoit and McElroy (2010) are able to estimate the correct placement of the $79 \%$ of the parties in their data-set $(n=146)$. These overall figures can be further disaggregated per political Group and macro-region (Old vs New Europe) as to provide a more fine-grained picture (Table 3).

The probability ratios for the political Groups vary considerably. The model predicts very well the member parties of the EPP and the GUE, with $80 \%$ of correct predictions, and it does also a good job for the ECR, the Euro-skeptics (both about 71\%) and the S\&D (about 69\%). The lower ratio of correct prediction is for the ALDE, where barely one out of two parties is correctly predicted. The findings show that - among the three largest political Groups - the centrist ALDE has the weakest boundedness and its member parties are often classified as members either of the EPP or the S\&D.

Moving to the comparison between Western and Eastern Europe, we would expect a stronger misfit for the parties of the 'New' Members. As the entries in Table 3 show, this expectation is partly supported by the evidence. The overall percentage of correct predictions for the post-communist countries drops by about 20 percent, to 58.7. However, both for the EPP and the S\&D, the percentage of correct predictions is only slightly lower. Both in the West and in the East, it is the ALDE Group with the lowest percentage of correct placements. This is hardly surprising, given the wide meaning of the label 'liberalism' and the traditional division within the Liberal family among 'social' and 'market' liberals (Von Beyme, 1985:32-46). In Eastern Europe, the 'liberal' label has been further plagued by its widespread - and at times unjustified - usage in the early days of the democratization process.

If what national parties declare in their election manifestos is sufficient to classify more than twothirds of them in the correct grouping, it is worth focusing on the misplaced observations to see if any pattern emerges. First, however, it shall be added that for another 13 percent of the parties (10 in the 'Old' and 8 in the 'New' Europe) the second prediction is the correct one. Hence, only the

\footnotetext{
13 If we apply a majority rule, predicting every national party in the modal outcome category (the EPP), we would
} obtain the 29 percent of correct predictions (EPP members / $n$ sample) 
fifteen percent of the parties is completely misclassified. At this point, some reflections on the misplaced parties are necessary.

First, we found before some evidence on the importance of pragmatic incentives. The Model corroborates our previous findings by predicting, for instance, the Italian Democrats as a most likely member of the ALDE Group. If the programmatic statements written in its Euromanifestos bring it closer to the ALDE position, a party with 'majoritarian vocation' knows that its influence in the Chamber is maximized by joining the bigger S\&D.

In some other cases, 'domestic politics' is likely to have had an effect on Group choice. When more than one national party is a potential member of a political Group, party competition and electoral tactics 'at home' can be important. It has already occurred in history that a member party of a political Group has vetoed the candidature of another party from the same country. Membership in a political Group can be an important factor of legitimization - especially for new parties in search of identity and recognition. ${ }^{14}$

Third, some measurement error needs to be taken into account. It is probably more than a coincidence that several of the wrongly classified parties issued very short Euromanifestos. As it has been demonstrated in the literature on party manifestos (Gabel, Huber, 2000), short documents provide too limited information. The computation of policy scales is problematic and the resulting placement of the parties inconsistent. As a first illustration of this problem, it shall be noted that the average length of the Euromanifestos in our sample amounts to 497', while the average for the wrongly-classified parties amounts to 346 and, for Eastern members, to only 174 'quasi-sentences'.

Finally, out of the total number of parties wrongly classified in the East European region, about half belongs to Latvia and Lithuania. It shall be noted that the same two Baltic countries have been described as the most resilient to left-right classifications among the new EU members (Klingemann et al., 2007:15, 25). This finding is confirmed here, where it is shown that several of their parties are, indeed, at odds with the existing party configuration in the EP.

14 For instance, the Italian People's Party (PPI) has vetoed for several years the entry in the EPP Group of Silvio Berlusconi's Forza Italia (FI). Eventually, the largest and most successful FI, until then isolated in the Parliament, was accepted in the EPP. After some years of uneasy coexistence, the PPI left the EPP and entered the ALDE. 
Table 6.3: Classification of the national parties in the political Groups

\begin{tabular}{|c|c|c|c|c|c|c|c|c|c|c|c|c|c|c|c|c|}
\hline & \multicolumn{2}{|c|}{ EPP-ED } & \multicolumn{2}{|c|}{ S\&D } & \multicolumn{2}{|c|}{ ALDE } & \multicolumn{2}{|c|}{ GREENS } & \multicolumn{2}{|c|}{ GUE/NGL } & \multicolumn{2}{|c|}{ ECR } & \multicolumn{2}{|c|}{ EFD } & \multicolumn{2}{|c|}{ Total } \\
\hline & $N$ & $\%$ & $N$ & $\%$ & $N$ & $\%$ & $N$ & $\%$ & $N$ & $\%$ & $N$ & $\%$ & $N$ & $\%$ & $N$ & $\%$ \\
\hline $\begin{array}{l}\text { Correct } \\
\text { placement }\end{array}$ & 32 & 80 & 18 & 69.2 & 14 & 51.8 & 14 & 77.8 & 12 & 80 & 5 & 71.4 & 5 & 71.4 & 100 & 71.4 \\
\hline - Old Europe & 19 & 82.6 & 12 & 70.6 & 9 & 56.2 & 14 & 82.3 & 12 & 92.3 & 2 & 100 & 5 & 83.3 & 73 & 77.7 \\
\hline - New Europe & 13 & 76.6 & 6 & 66.6 & 5 & 45.4 & - & - & - & - & 3 & 60 & - & - & 27 & 58.7 \\
\hline $\begin{array}{l}\text { Correct second } \\
\text { placement }\end{array}$ & 4 & 10 & 2 & 7.8 & 7 & 25.9 & 2 & 11.1 & 2 & 13.3 & - & - & 1 & 14.3 & 18 & 12.9 \\
\hline - Old Europe & 2 & 8.7 & 2 & 11.7 & 4 & 25 & 1 & 5.9 & 1 & 7.7 & - & - & - & - & 10 & 10.6 \\
\hline - New Europe & 2 & 11.7 & - & - & 3 & 27.2 & 1 & 100 & 1 & 50 & - & - & 1 & 100 & 8 & 17.4 \\
\hline $\begin{array}{l}\text { Wrong } \\
\text { placement }\end{array}$ & 4 & 10 & 6 & 23 & 6 & 22.2 & 2 & 11.1 & 1 & 6.7 & 2 & 28.6 & 1 & 14.3 & 22 & 15.7 \\
\hline - Old Europe & 2 & 8.7 & 3 & 17.6 & 3 & 18.7 & 2 & 11.8 & - & - & - & - & 1 & 16.7 & 11 & 11.7 \\
\hline - New Europe & 2 & 11.7 & 3 & 33.3 & 3 & 27.2 & - & - & 1 & 50 & 2 & 40 & - & - & 11 & 23.9 \\
\hline Total & 40 & 100 & 26 & 100 & 27 & 100 & 18 & 100 & 15 & 100 & 7 & 100 & 7 & 100 & 140 & 100 \\
\hline
\end{tabular}

Key: Estimates from Model 3 


\section{Conclusions}

Using a multinomial logit model to classify national parties in the political Groups, informed only with their positions on some important policy scales, it has been possible to correctly predict the transnational affiliation of more than two national parties over three. To be sure, the possibility that other factors beside ideology or policy compatibility would matter for Group membership has not been totally ruled out. Thus, controlling for ideology, large parties are more likely to join the large rather than the small political Groups. Parties - and large national parties especially - are conditioned in their transnational affiliation by the pragmatic incentives and the office spoils that Group affiliation grants. Nonetheless, in the new EU-27, ideology or policy compatibility is, still, the main factor behind Group membership. In turn, this means that the political Groups are aggregations of like-minded parties, sharing - at a minimum - similar policy objectives. This is especially remarkable for the EPP and the S\&D which, including members from all the EU members, have been at times portrayed as mere 'catch-all' coalitions of national parties.

Our results are nicely mirrored by similar exercises in the literature (Bardi et al., 2010:1031; Klingemann et al., 2007:29-50; McElroy, Benoit, 2010) which, relying on different data and methods, corroborate the validity of our findings. In terms of substance, if national parties, grouping together at the EU level, confront their national voters with similar manifestos, then citizens throughout the EU already have the de facto possibility to choose from European alternatives. Thus, in terms of programmatic supply at least, the prospects for representative democracy at the EU level - as the Treaty of Lisbon emphatically declares - might not be as bleak as it is often suggested.

However, a more cautious conclusion has to be drawn about the integration of the ten postcommunist countries which entered the EU between 2004 and 2007. It has been shown that the general left-right dimension fails to discriminate the Eastern parties among the political Groups as neatly as it does for Western Europe. Furthermore, the percentage of correct predictions for East European parties is twenty percent lower than in the West. On the one hand, these findings might indicate that the 'new' parties still need some time to sort themselves in the 'correct' political Group or, rather, that they are more likely to pursue pure office goals. On the other hand, however, problems of classification might also originate from the data: the average Euromanifesto in Eastern Europe is considerably shorter and, consequently, more problematic for the estimates. As for party manifestos in general, further research on the role that election platforms have in different national context and for different parties would be welcomed. 


\section{References}

Bardi, L., Bressanelli, E., Calossi, E., Gagatek, W., Mair, P., Pizzimenti, E. (2010), How to Create a Transnational Party System, Florence, EUDO Report 2010/2.

Braun, D., Mykhaylov, S., and H. Schmitt (2010) EES (2009). Manifesto Study Documentation Advance Release (user beware / pre-release B), www.piredeu.eu

Budge, I., Klingemann, H. D., Volkens, A., Bara, J., and E. Tanenbaum (2001) Mapping Policy Preferences. Estimates for Parties, Electors, and Governments: 1945 - 1998, Oxford, Oxford University Press.

Budge, I., Robertson. D., and D. Hearl (1987), Ideology, Strategy and Party Change: spatial analysis of post-war election programmes in 19 democracies, Cambridge, New York, Cambridge University Press.

Corbett, R., Jacobs, F., and M. Shackelton (2007), The European Parliament, London, Cartermill Press, $7^{\text {th }}$ edition.

EES (2009), European Parliament Election Study 2009, Manifesto Study Data, Advance Release (user beware / pre-release B), 22/07/2010, www.piredeu.eu

European Parliament (2009) Etudes sur le systeme d'attribution des rapports dans les commissions parlementaires, Brussels: Directorate for Relations with the Political Groups.

Fabbrini, S. (2006), Il falso problema della collocazione europea, “Reset”, 98, pp. 8-11

Gabel, M. J., and J. D. Huber (2000), Putting Parties in Their Place: Inferring Party Left-Right Ideological Positions from Party Manifestos Data, “American Journal of Political Science”, 44, 1, pp. 94-103.

Gozi, S. (2003), Le elezioni europee 2004. Se viene il tempo della politica, "Il Mulino", pp. 11211133

Hix, S., Noury, A., and G. Roland (2007), Democratic Politics in the European Parliament, Cambridge, Cambridge University Press.

Hlousek, V., and L. Kopecek (2010) Origin, Ideology and Transformation of Political Parties, Farnham, Ashgate.

Hoyland, B, and J. F. Godbout (2008), Lost in Translation? Predicting Party Group Affiliation from European Parliament Debates, Unpublished Manuscript, 2008.

Katz, R. S., and P. Mair (1995), Changing Models of Party Organization and Party Democracy: the Emergence of the Cartel Party, "Party Politics", 1, 1, 1995. 
Klingemann, H. D., Volkens, A., Bara, J. and I. Budge (2007), Mapping Policy Preferences II: Estimates for Parties, Electors and Governments in Central and Eastern Europe, European Union and OECD 1990-2003, Oxford, Oxford University Press.

Lipset, S. M. and S. Rokkan (1967), Cleavage Structures, Party Systems and Voter Alignments: an Introduction, in S.M. Lipset and S. Rokkan (ed.), Party Systems and Voter Alignements. Cross National Perspectives, New York, The Free Press, pp. 1 - 64

Lynch, P. and R. Whitaker (2008), A loveless marriage. The Conservative and the European People's Party, "Parliamentary Affairs", 61, 1, pp. 31-51.

Long, S. and J. Freese (2006), Regression Models for Categorical Dependent Variables using STATA, STATA Press.

Lowe, W., Benoit, K., Mikhaylov, S., and M. Laver (2008), Scaling Policy Preferences from Coded Political Texts, paper presented at the ECPR General Conference, Potsdam, Sept. 10-12.

Jansen, T. (2006), The Emergence of a Transnational European Party System, "European View”, 3, pp. $45-56$

Johansson, K. M. (1997), Transnational party alliances: analysing the hard-won alliance between Conservatives and Christian-Democrats in the European Parliament, Lund, Lund University Press Mair, P. and C. Mudde (1998), The Party Family and its Study, “Annual Review of Political Science", 1, pp. 211-229

Marquand, D. (1978). Towards a Europe of the Parties, The Political Quarterly, 49, pp. 425-445

Maurer, A., Parkes, R. and M. Wagner, Explaining group membership in the European Parliament: the British Conservatives and the Movement for European Reform, Journal of European Public Policy, 15, 2, pp. 246-262

McElroy, G. and K. Benoit (2007), Party Groups and Policy Positions in the European Parliament, "Party Politics", 13, 1, pp. 5-28.

McElroy, G. and K. Benoit (2010), Party Policy and Group Affiliation in the European Parliament, "British Journal of Political Science", 40, pp. 377-398

Roa Bastos, F. (2009), The Role of European Electoral Programmes, in Democracy in the EU and the Role of the European Parliament, Rome, Quaderni IAI, 14, pp. 43-55

Schmitt, H. and J. Thomassen (2004), Democracy and Legitimacy in the European Union, in H. M. Narud and A. Krostad, Elections, Parties and Political Representation, Universitetforslaget, 2004, pp. $375-408$

Settembri, P. (2004) When is a group not a political group? The dissolution of the TDI in the 
European Parliament, 10, 1, pp. 150-174

Thomassen, J. J. and H. Schmitt (2009), The EU party system after eastern enlargement, "Journal of European Integration", 31, 5, pp. 569-588.

Trechsel, A. H. and P. Mair (2009), When Parties (also) Position Themselves: an Introduction to the EU Profiler, EUI - RSCAS Working Paper, 65.

Van Oudenhove, G. (1965), The Political Parties in the European Parliament: The First Ten Years, Leyden, A.W. Sijthoff.

Volkens, A. (2006) Policy Changes of parties in European Parliament party groups, in J. Bara and A. Weale, Democratic Politics and Party Competition, Abingdon, Routledge, pp. 56-82

Von Beyme, K. (1985), Political Parties in Western Democracies, Aldershot, Gower Publishing. 